\title{
Evidence by Multi-Scale Analysis of Lineaments Derived from Gravity Anomalies in the Batouri Area (Eastern-Cameroon)
}

\author{
Ngoumou Paul Claude ${ }^{1}$, Owona Angue Marie-Louise Clotilde², Bikoro Bi Alou Marcelin ${ }^{3}$, \\ Wandji Kamwa Joseph Antoine ${ }^{4}$, Owono Amougou Olivier Ulrich Igor ${ }^{5}$, Ndougsa Mbarga Théophile ${ }^{6}$ \\ ${ }^{1}$ Department of Physics, Faculty of Science, University of Yaoundé I, P.O. Box 812, Yaoundé, Cameroon. \\ ${ }^{2}$ Department of Physics Advanced Teachers’ Training College, University of Yaoundé I, P.O. Box 47 Yaoundé Cameroon. \\ ${ }^{3}$ Department of Earth Sciences, Faculty of Science, University of MarouaI, P.O. Box 46, Maroua, Cameroon. \\ ${ }^{4}$ Department of Physics, Faculty of Science, University of Yaoundé I, P.O. Box 812, Yaoundé, Cameroon. \\ ${ }^{5}$ Department of Physics, Faculty of Science, University of Yaoundé I, P.O. Box 812, Yaoundé, Cameroon.
}

${ }^{6}$ Department of Physics Advanced Teachers’ Training College, University of Yaoundé I, P.O. Box 47 Yaoundé Cameroon.

\begin{abstract}
The area study of Batouri is known for its artisanal mining of gold and other minerals. The aim of this study is to determine the composition distribution of the area likely trap mineralization or fluid flow from the gravity data. This study is conducted in southeastern Cameroon, combines various data processing techniques including horizontal gradient gravity coupled with upward continuation and Euler deconvolution. The results from the different interpretations have established the superficial and deep structural map from which a beam was identified vulnerabilities organized following directions: NS, NW-SE, NE-SW, ENE-WSW and WNW-ESE respectively to a depth of 2,4 to 16,5 kilometers. The prevailing direction of lineaments here is the structural mapping $N W$-SE. The axis ensuing different interpretations of observed anomalies, as a basis for future mining and hydro geological studies in the area.
\end{abstract}

Keywords: Bouguer Anomaly, Horizontal Gradient, Upward Continuation, Euler Deconvolution, Lineament

\section{Introduction}

The Batouri area is located in South-East Cameroon, between the meridians $14^{\circ} 00^{\prime}$ and $15^{\circ} 00^{\prime}$ Longitude East and parallel $4^{\circ} 00^{\prime}$ and $5^{\circ} 00^{\prime}$ Latitude North.The gravimetric method used in this study measures variations in the earth's gravitational field due to the density contrast between the basement rocks to determine the shape and constitution of the earth. That field has been the subject of several geophysical and geological studies. It is characterized by many major structures of which the nature and direction remains unclear.

The Bouguer anomaly Map (Fig. 3) shows that the gravimetric relief of the zone is disturbed according to the general direction NW-SE by discrepancies gradients or different density contrasts. This map reflects excesses defects of relative masses of the heterogeneity of the density of rock formations in the basement of the region which are the result of the superposition of the effects of deep and shallow geological structures.These gradients would reflect discontinuities or interfaces such as faults and flexures. For the study of these discontinuities, we applied the method of multi-scale analysis based on the horizontal gradient coupled with the upward continuation, Euler deconvolution and so the goal will be to determine the depth of the underlined tectonic by the first two methods.

\section{Geological and Tectonic Setting}

The Batouri-East zone (Fig. 1) is part of the Cameroonian center area, which extends from southern Poli in southern Bafia. It contains syntectonic granitoids and orthogneiss hyper potassium trend aluminium and dated formations [1]. From a geological perspective, the area has two major advantages:

- It is the Pan-African margin of the transition zone resulting from the collision Pan-African belt (CPNE)-Craton of Congo (CC) as it sits a little further north of latitude $4^{\circ} 00^{\prime}$ (Fig. 1), and specifically in the northern margin of the transition zone CPNE-CC neoproterozoic formations characterized by the Cameroonian base (base Complex). Moreover, from the tectonic point of view, the area lying south of the accident at the Sanaga Fault (FS) and Shear Cameroonian Centre (CCC) carries the mark of a strong magmatic activity characterized by plutonic rocks lifts [2$3]$ that are granites of various compositions. Among the geological formations identified in the area, we have: eruptive formations (granites intrusions), nonmetamorphic sedimentary formations and metamorphic formations (base complex) which are mainly granites and migmatites rejuvenated during the Pan-African orogeny;

- It presents indices of gold veins some of which have been the subject of a detailed characterization for potential exploitation at the economic purposes [4-5-6]. 


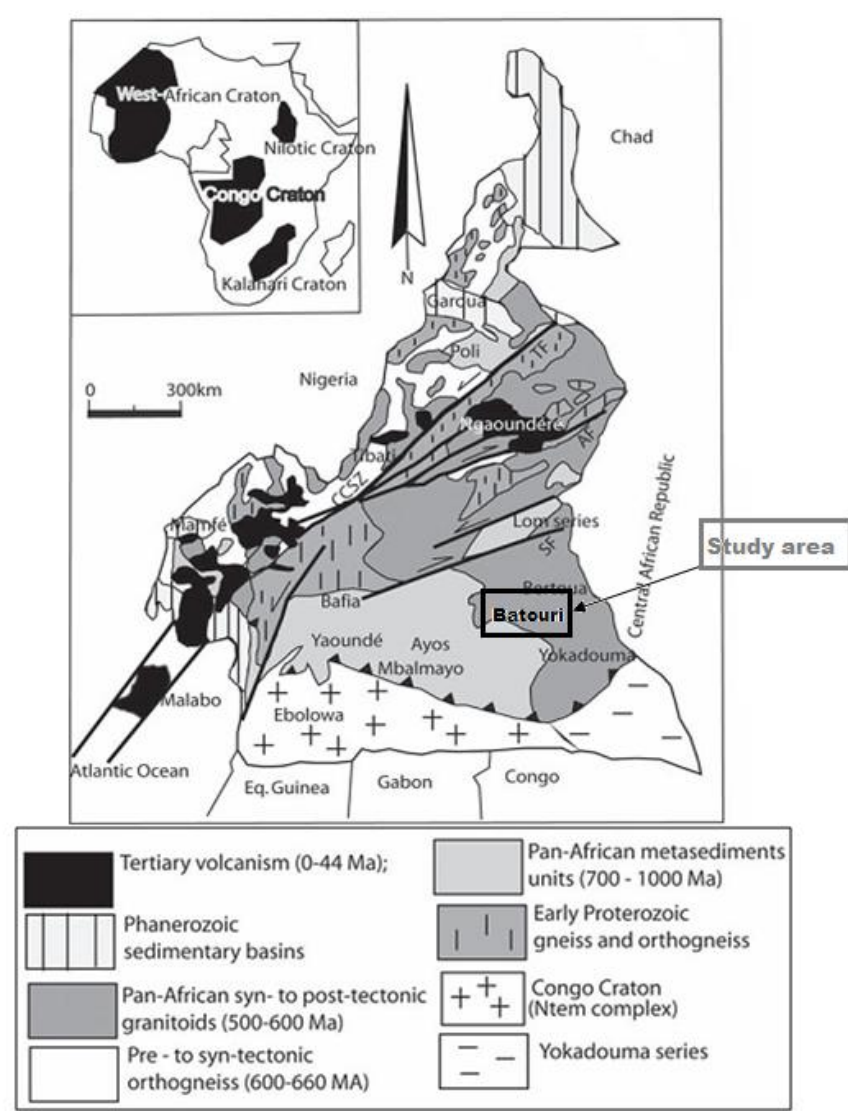

Figure 1: Geological Map of Cameroon ([5], modified) showing the location of the study area and the main lithotectonic units: $\mathrm{CCC}=$ Central Cameroon Shear; $\mathrm{FS}=$ Sanaga Fault; FTB= Tibati-Banyo Fault; NT= Ntem Complex; $\mathrm{SD}=$ Dja Series, $\mathrm{SN}=$ Nyong Series.

\subsection{Eruptive formations}

They consist mainly of Colomine granitic rocks at west of Boden. They constitute intrusions including former syntectonic granites, syntectonic granites of late and posttectonic granites in a metamorphic encasement formed by plutonic or granitization between 500-600Ma (Fig. 2) [7].

\subsection{Non metamorphic Sedimentary formations}

They are divided into two groups namely: The subsurface formations essentially free:

- Observed particularly in the alluvial Lom valley of the Kadeï and Doumé;

- Eluvial deposits encountered throughout the region and especially in granitic and gneissic areas, shale plays, quartzites areas;

- The laterites are abundant in the area and may have ferruginous shales or origins;

- Terrace River along the cliff of Mari north of Betare-oya. Coverage formations characterized by the absence of sedimentary trace. But it is good to report during surveys carried out in the East; it was found gravels whose appearance is quite characteristic of sand stone facies in the threshold of Badongoue and Batouri.

\subsection{Base Complex}

It is a Precambrian metamorphic rock whose formation is the result of metamorphism that affected the sedimentary deposits, probably of marine origin[2].It is divided into three families:

- The Ectinites which are: the lower gneiss encountered south of Batouri; amphibolites to grano-blastic oriented texture and melanocrate encountered Northwest Batouri; the type orthogneiss with crushed quartz secondary recrystallization is observed in northern Batouri;

- The Migmatites that are: diadysites we meet in south of Batouri and presenting as a frank ectinite seams with filler or inter bedded or cutting across the benches; elsewhere we distinguish the embrechites as formation that extended to South East Batouri and anatexies found in the Southeast region Batouri as biotite, amphibole and garnet.

- The ancient metamorphic or epimetamorphic series, this is a volcano-sedimentary formation forming a band oriented northeast and southwest in the Lom Valley, from where comes the appellation, the Lom series. It covers an area of $2,500 \mathrm{~km}^{2}$, from the Central East of Cameroon to the Central African Republic (CRA). It has a sigmoid shape $200 \mathrm{~km}$ long and 10-30 km wide [8]. Based on the work of [2], sedimentary deposits in this series are of continental origin, made up of sand, clay, marl and arkose. These sediments were transformed into shale (seritoschistes, choritoschites, schites graphitic, garnet schists) and quartzite (coarse conglomeratic quartzites, quartzite medium grained, fine-grained quartzites).

- The Pan-African center field which owns the area was affected by major tectonic faults in connection with the opening of the South Atlantic including: Central Cameroonian shear as ductile fault accident and the Sanaga as brittle accident [3].

- Structural studies performed in the region (Fig. 2) show that it was affected by three phases of deformations [1].

- The First $D_{1}$ deformation phase is responsible for the cleavage $\mathrm{S}_{1}$, lineation $\mathrm{L}_{1}, \mathrm{C}_{1}$ and shear plies $\mathrm{P}_{1}$;

- The $\mathrm{D}_{2}$ phase is associated with the development of granitoid intrusions syn- $\mathrm{D}_{2}$, mental parallel regional structures. It is characterized by $\mathrm{S}_{2}$ schistosity, lineation $\mathrm{L}_{2}, \mathrm{P}_{2}$ folds and shear $\mathrm{C}_{2}$;

- The $\mathrm{D}_{3}$ phase is marked by shearing together with $\mathrm{C}_{3}, \mathrm{P}_{3}$ folds.

During and after the orogenic phenomena, the base of the area suffered numerous fractures and broken points difficult to observe. But it is noted that the area is maintained by a network of faults assumed NNE- SSW direction [7]. 


\section{International Journal of Science and Research (IJSR) \\ ISSN (Online): 2319-7064}

Index Copernicus Value (2013): 6.14 | Impact Factor (2014): 5.611

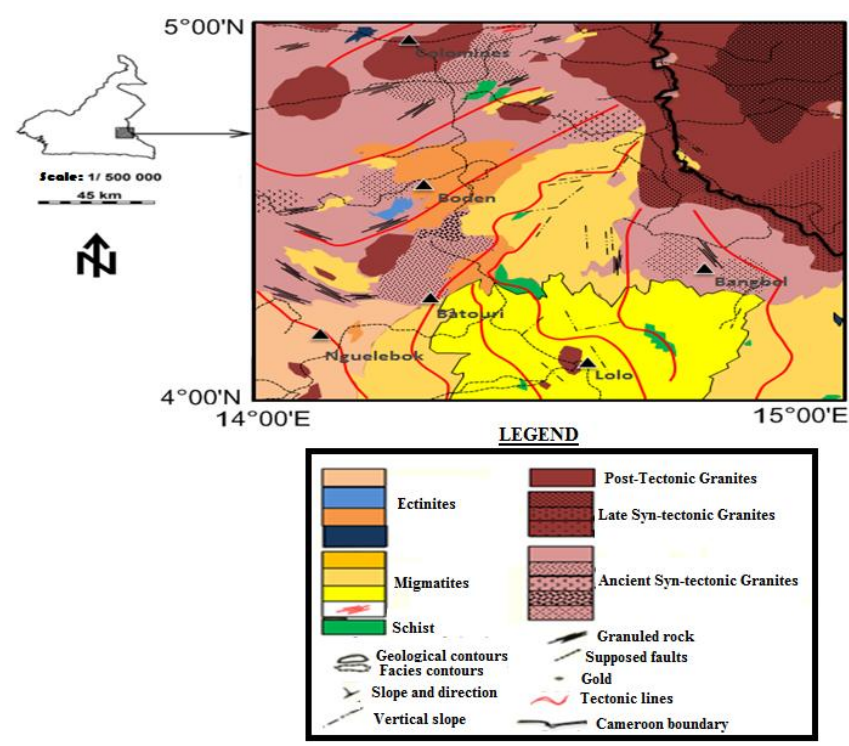

Figure2: Geological map of the study area ([7], modified)

\section{Gravity Data}

The gravity data available for this study were obtained through recognition campaigns on essential Cameroonian territory by the research group OSRTOM respectively (Overseas Office of Scientific and Technical Research) between 1963 and 1967, and then followed by significant improvement on areas prospected by Poudjom in 1996[9]. The gravity readings were corrected for drift and the gravity anomalies computed were assuming a mean crustal density of $2.67 \mathrm{~g} / \mathrm{cm}^{3}$. The maximum error in the Bouguer anomaly value for any of the stations due to an error in height determination was not expected to exceed $0.15 \mathrm{mGal}$.These data coming from the unequalled potential field distribution in different sub-surface zones collected between basic recording stations situated at intervals of $5 \mathrm{~km}$ after recording measurements and applications of different corrections. They have permitted to establish a contour map using the gravimetric Oasis montaj 8.0 of Geosoft software. The type of projection of the coordinate system used here is WGS 84 / UTM (Universal Transverse Mercator) Zone 33 North.

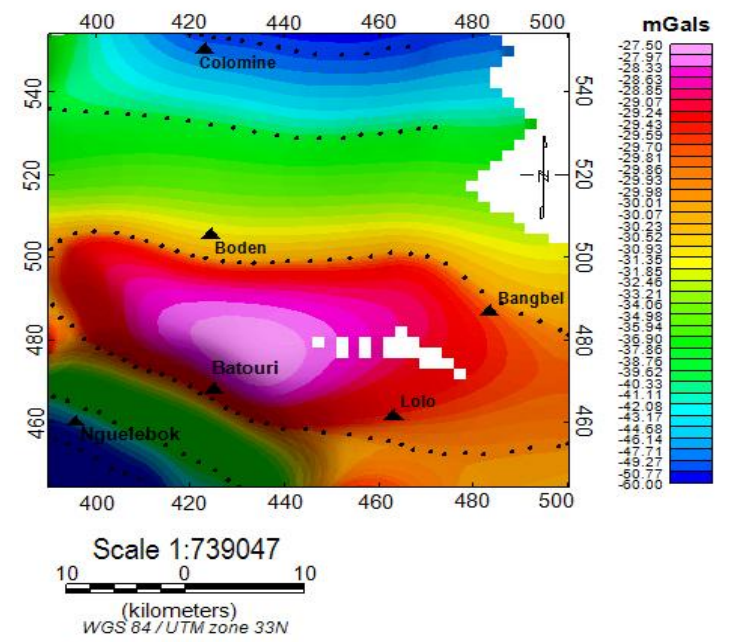

Figure 3: Bouguer anomaly map, black triangles indicate the localities and black round dots indicate gravity stations.

\section{Methods}

Gravimetry is a geophysical method based on the study of the gravity field. It consists in measuring the acceleration variation of gravity using a gravimeter and then applying to the raw values, corrections (Faye correction or outdoors, Tea correction, correcting or topographic relief, latitude correction, lunisolar correction) to eliminate the influence of celestial bodies, the rotation and shape of the earth in order to highlight the anomalies attributable to variations in the density of the basement [10].

The processing of data obtained allows to produce isostatic maps of Bouguer anomalies, and whose interpretation will lead either to a qualitative geological field study that might contain the desired resources, that provides quantitative study of geometrical and physical parameters in this environment [10-11].

The intensity of gravity measured at a point translated simultaneously, the effects of all the masses of the earth, of all topographic, and all the contrasts of densities inside the globe.

The gravity anomaly is the difference between observed gravity and some theoretical value of gravity predicted at the measurement point. The gravity anomaly maps express the density anomalies in the superficial Situated both land and in the basement.

\subsection{Horizontal Gradient and Upward Continuation}

The horizontal gradient is the simplest approach to identify areas of geological contacts sources of high density (or excess weight) in the soil [12]. Its importance lies essentially in its calculation by the first derivates (along the $\mathrm{x}$ and $\mathrm{y}$ axis directions) of the gravity field in the horizontal plane. For any point $\mathrm{M}(\mathrm{x}, \mathrm{y})$ where the anomaly of gravity is located, the magnitude of the gradient Horizontal (AGH) to a direction of the contacts is given by the relation:

$$
\operatorname{AGHM}(x, y)=\sqrt{\left(\frac{\partial M}{\partial x}\right)^{2}+\left(\frac{\partial M}{\partial y}\right)^{2}} \text { (1) [13-14]. }
$$

The horizontal derivative, in a given better management allows identifying a contact between two different densified environments. The horizontal gradient map highlights areas with abrupt exchange in density, as interpreted either faults or geologic contacts, as intrusive formations.

The implementation of this method to a gravity map shows that local maxima forming the horizontal gradients form narrow lines above abrupt exchange in the density [15].

The upward continuation is a separation technique of abnormalities according their nature. In this calculation method, the field's measurement plan is projected to a field plan situated in altitude. The upward continuation alleviates the effect of superficial sources and to highlight regional anomalies [16].

\subsection{Euler Deconvolution}

It is a filtering technique which is used to locate in the 


\section{International Journal of Science and Research (IJSR) \\ ISSN (Online): 2319-7064}

Index Copernicus Value (2013): 6.14 | Impact Factor (2014): 5.611

horizontal plane of the contacts and then estimate their depths from gravity or magnetic anomalies [17]. It can be applied to any homogeneous field, including gravity data of the Bouguer anomaly field because it is particularly used to trace the surface of the ground contacts. For our anomalous field, the degree of homogeneity is described by the structural index $(\mathrm{N})$ of contact between localized linear structures [17-18] and it is defined according to Euler's 3 dimension equation as:

$$
\left(x-x_{0}\right) \frac{\partial T}{\partial x}+\left(\mathrm{y}-\mathrm{y}_{0}\right) \frac{\partial T}{\partial y}+\left(z-z_{0}\right) \frac{\partial T}{\partial z}=N(B-T)
$$

Where $(\mathrm{x}, \mathrm{y}, \mathrm{z})$ is the observation point and the coordinate $\left(\mathrm{x}_{0}, \mathrm{y}_{0}, \mathrm{z}_{0}\right)$ is the position of the gravity field at a point $\mathrm{T}$ on the Bouguer B (x, y, z).

The structural index $(\mathrm{N})$ is defined according to the type of structures surveyed. Thus, it is disclosed that an index $\mathrm{N}=1$ is best suited for low-vertical faults rejection, and an index $\mathrm{N}$ $=0$ for the great faults rejection, and an index of $\mathrm{N}=0.5$ for intermediate cases.

\section{Results}

\subsection{Analysis and Interpretation of Gravity Data}

Map of gravity anomalies (Fig. 4) reflects excess and ground faults on the heterogeneity of the rock density at the base of the formations of the region. It is the result of superpositions of the effects of the superficial and deep geological structures. The complete observation of this card puts an emphasis on anomalies with negative isogales and spaced an average of $5 \mathrm{mGals}$; whose amplitudes values vary between $60 \mathrm{mGals}$ for the mild abnormalities and $-27 \mathrm{~m}$ Gals for the heavy abnormalities. It also shows that the gravimetric relief is disrupted following the general direction NW-SE. The distribution of defects shows that:

- The locality of Batouri is underlined by a heavy anomaly approximately $-27 \mathrm{mGals}$ between the longitudes 14 and 15 degrees, up to the parallel $4^{\circ} 30^{\prime}(500 \mathrm{~km})$ oriented WNW-ESE to WE. This anomaly follows a closed, rounded contour in the form of an ovoid in its central part, to which it first goes to Western Bangbel and Lolo and three iso-lines abnormal -29 mGals. This heavy anomaly is bounded by the North southern to areas of relatively heavy highlighted anomalies between -30 and$31 \mathrm{mGals}$ and those moderately light sub horizontal at the height of $520 \mathrm{~km}$ paralleled by the respective anomalies 32 to -39 mGals;

- In the north-eastern study area, there are slight anomalies 60 mGals of general orientation EW up to Colomine;

- Between the meridians 380 and $440 \mathrm{~km}$, but this time in southern parallel $480 \mathrm{~km}$, we have a big negative anomaly that calibrates Nguelebok. Its direction is first NW-SE along the latitude $460 \mathrm{~km}$ south west of Batouri and NE-SW in the Bangbel-Lolo axis. This major negative anomaly is limited in the direction East by North at a moderately slight defect as described above with amplitude ranging from -34 to -40 mGals.

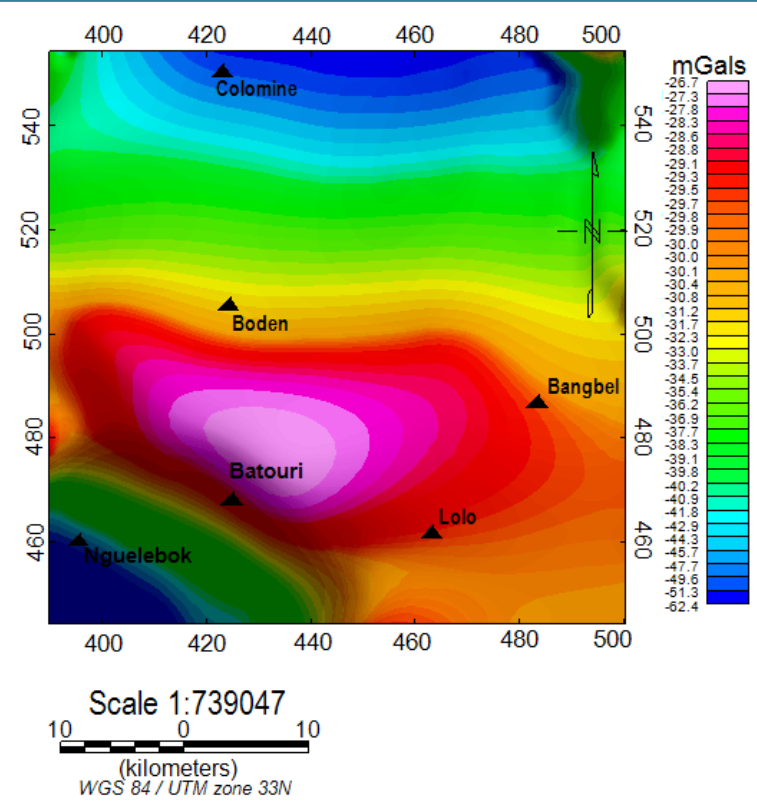

Figure 4: Map of Bouguer anomalies of the Batouri area.

Gravity anomalies in the area of Batouri cover both granitic gneiss formations but also the training base complex, sometimes covered sediments and magmatic lifts.

When looking at the map of Bouguer anomalies (Fig. 4) above, it was quickly captivated by the general directorate of anomalies marked by important gravimetric axes that go great with executive noticed tectonics in collision the Congo Craton and the Panafrican belt along parallel $4^{\circ} 00^{\prime}$ (Group Yaoundé). In addition, this major tectonic management highlighted by the wide heavy anomaly -27 mGals (Batouri) oriented WNW-ESE is the signature of the Pan-African granitoids and specifically the contact between granite rocks and the base complex (Neoprotozoic formations) (Fig. 5.b). Furthermore, the source of the anomaly consists of highly dense rocks (heavy masses) causing lifting of the base is a bulge of the crust. As for the approximation of isogales with the topographical map, it proves that they correspond to the reliefs low elevations of 500-600 meters (Fig. 5.a).But also that the management of this anomaly is drained by the whole river system of the region, so the hypothesis of a strong tectonic activity or potential orientation of fractures in this pan-African coverage.

Note also on this card, precisely in the North flank Colomine, a peak of -60 mGals materialized by a tightening of iso-lines with anomalous drawing the most important form of vacuoles by its wavelength oriented E-W as intrusion mark various granites compositions described by the plutonism at north of the region (Fig. 5.b).

To interprete the narrow and light anomalies in the Colomine area, we suggest the presence of small rocks (plutonic) stuck along the fault plane that affects the bedrock. Moreover, we can situate the source of this anomaly at the base of the crust, following a collapse of the base of the crust to the mantle due to the absence of metallic materials in depth. Or sagging of the base, due to the increase of the sedimentary cover (Fig. 6). When the link between the topographic relief of Batouri and negative iso-anomalous lines observed in this sector, this signature is characteristic of the valleys forming a bowl (Fig. 


\section{International Journal of Science and Research (IJSR) \\ ISSN (Online): 2319-7064 \\ Index Copernicus Value (2013): 6.14 | Impact Factor (2014): 5.611}

5.a) that extends to the east by the peneplains (reliefs of very high altitudes)

Similarly, in the southwest side of the area, it is noticed a lay out tightened iso-anomalous westward. The drawing of such iso-anomalous; seems largely influenced by the secondary tectonic management WNW-ESE. It would thus mark a fracture direction and therefore flaws in this location (Fig. 6). In the region, the result meta sediments of the intermediate series whose tectonics is attributed to the thinning of the crust.

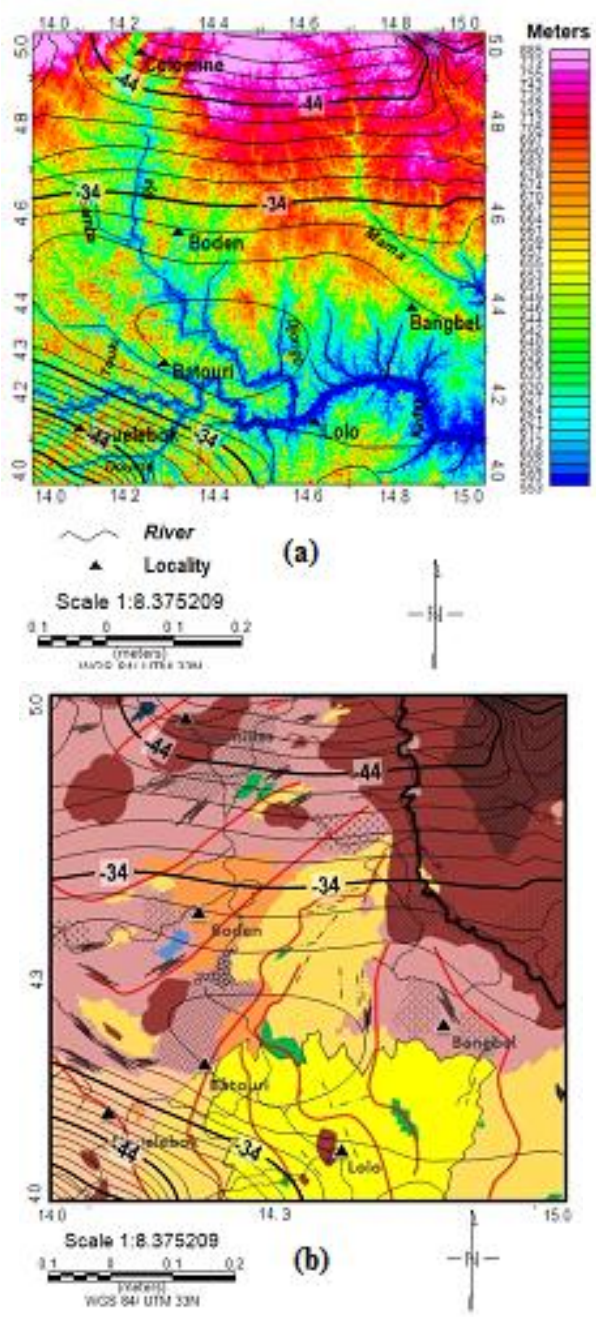

Figure 5: (a) overlay of isogales Bouguer anomaly map with the topography and (b) with the geology of the Batouri

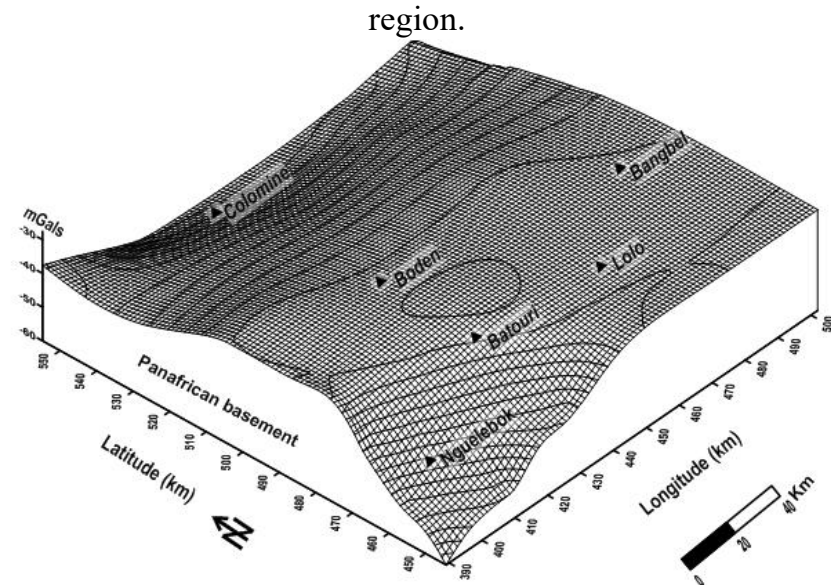

Figure 6: 3D-view of the basement in the Batouri-Boden region

\subsection{Horizontal Gradient and Maxima Map}

The horizontal gradient is a technique used by many authors [12-19-20-21] in order to interprete and detect structural injury, and abnormal contacts regardless of their orientations. Its maximum values are indicative of lateral density contrasts that we interpret by geological contacts or structural accidents.

In addition, the geometry of a gradient zone gives an idea of the type of geological structure. Thus, gradients having an elongate ridge more or less correspond to the straight sub vertical geological faults and contacts, while those having a peak draws a rounded contour often revealing the presence of a subsurface igneous intrusion, a salt dome or diapir [22].

Figure 7 shows the map of horizontal gradient to the region. It issues to the grid data Bouguer anomaly by applying the square root of the sum of the amplitudes of the two horizontal derivatives.

This map highlights two areas of positive and negative gradients sub horizontal separated by the contour value 0 $\mathrm{mGal} / \mathrm{km}$ of direction EW variable between Boden and Bangbel. One also distinguishes two zones respectively of type contact / fault and those corresponding to the presence intrusive structures around the Batouri-Lolo axis. Hence:

- North of Nguelebok up to $500 \mathrm{~km}$ (north of Batouri), we observed the contacts intensities ranging from $0 \mathrm{mGal} / \mathrm{km}$ to $1.59 \mathrm{mGal} / \mathrm{km}$ oriented NW-SE. These values suggest a brand of lineaments hidden in the covers of the complex and reflect a significant tectonic activity experienced by the region (Fig. 6).

- In Colomine area following the direction NW-SE, there is contact of low intensities and sometimes having an elongated oblong shape. These low gradients highlight a lot of intrusive bodies in the Pan-African granites or the presence of bowl.

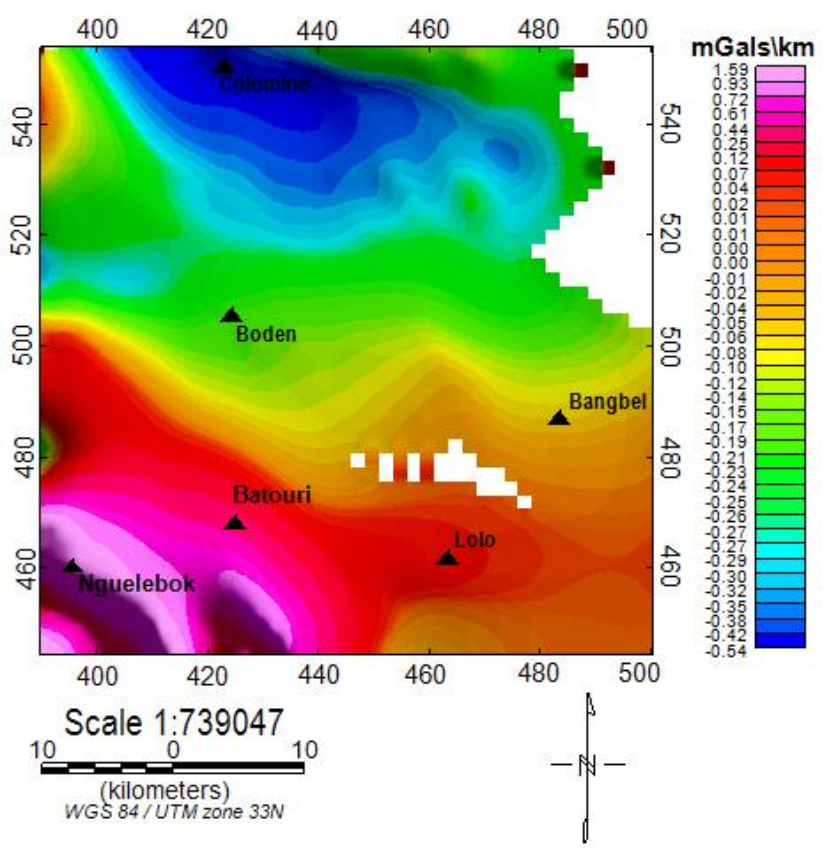

Figure 7: Horizontal gradient map of simple Bouguer anomalies. 


\section{International Journal of Science and Research (IJSR) \\ ISSN (Online): 2319-7064}

Index Copernicus Value (2013): 6.14 | Impact Factor (2014): 5.611

5.3. Multi scale Analysis of gradient maxima and mapping lineaments

Map of maxima of prolonged Bouguer horizontal anomalies gradient upwards $(2 \mathrm{~km}, 4 \mathrm{~km}, 8 \mathrm{~km}, 12 \mathrm{~km}$ and $14 \mathrm{~km})$ shows the interpreted zones either as geological contacts or faults, or as intrusive formations corresponding to lineaments (Fig. 8). The degree of importance of each lineament is determined by the continuous presence of the one to altitudes increasingly high extension. The analysis of the maxima of the horizontal gradient of the extended Bouguer anomaly map at different heights (Fig. 7) shows in the ColomineBangbel area and Boden, the lineaments with a vertical dip, while in the area and Batouri-Nguelebok they are sub horizontal to Northwest respectively.

The horizontal gradients and their maxima were calculated using the software Oasis montaj 8.0 in choosing indices 0.5 ; $1.0 ; 1.5 ; 2.5$ and 3 respectively for the different extended heights. The superposition of the local maxima of the horizontal gradient determined on the Bouguer extended up to a range of altitudes to $14 \mathrm{~km}$ allowed to realise the map in Figure 8.

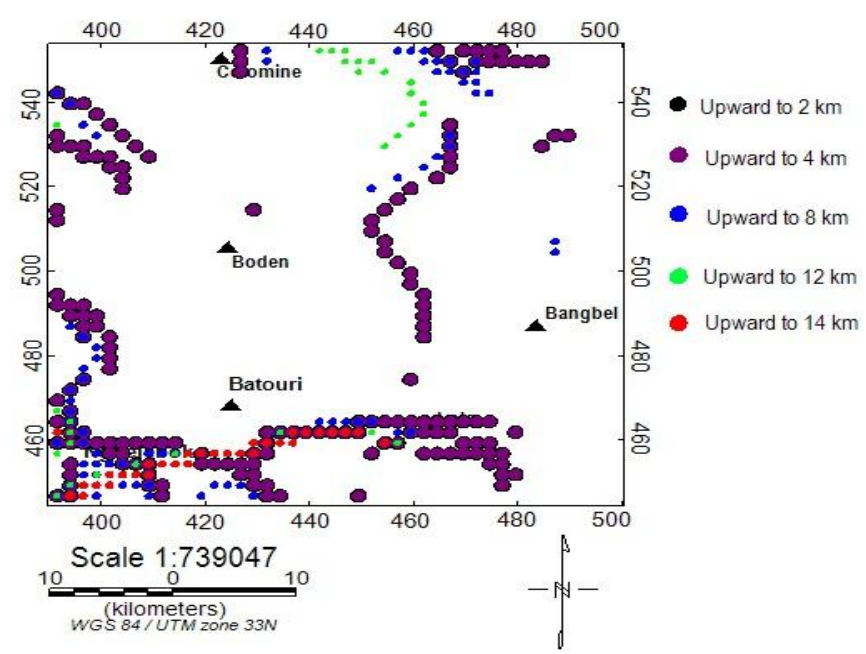

Figure 8: Maxima map of the horizontal gradient of the Bouguer anomaly map upward continued to 2, 4, 8, 12 and $14 \mathrm{~km}$ respectively.

\subsection{Depths from Euler Deconvolution}

The objective of the Euler deconvolution is to produce a map, after the resolution of the equation based on least squares, suitable for the location and identification of corresponding depths of geological structures created by magnetic or gravity anomalies. To apply it, we employ the Oasis montaj 8.0 software in using the least squares to solve the Euler equation so that to obtain simultaneously for each position of the maxima of a grid (the position of the source of abnormality, depth, and Basic density for a source). [18], [17] have shown that for the low index structural of from 0 to 1 , there are the best estimates of depths and bundled solutions. Moreover, [23] noted that the appropriate choice of the window size depends on the wave length of the anomaly examined and the size of grid. Therefore, in this study the following parameters have permit reflect the morphological status of the study area:
- A structural index $\mathrm{N}=0.0$ (wide-fault release);

- A moving window $3 \mathrm{~km}$ x $3 \mathrm{~km}$;

- A step tolerance in estimating the depth $Z=10 \%$;

The analysis of the map of Euler solutions (Fig. 10) shows the contacts of type faults have given the depths ranging from $2.4 \mathrm{~km}$ to $16.5 \mathrm{~km}$. The non-uniformity of the depths of said contacts in the area suggests that all the outlines of the box do not have the same origin.

Furthermore, the absence of data between Northern and South of Batouri-Boden axis materializes almost NNW-SSE line contact between the ancient metamorphic formations of the base complex and the post tectonic granites syntectonic or intrusive bodies of the Pan-African.

Also between Nguelebok-Batouri axis, there is a grouping of solutions on almost straight metamorphic formations, ancient metamorphic series and shale intrusions this suggests the existence of vertical contact or normal faults that go down 9 $\mathrm{km}$ NW-SE oriented EW and ENE-WNW a depth of $4 \mathrm{~km}$. This map also shows north of the deepest Boden contacts or faults $(16.5 \mathrm{~km})$ oriented EW, NW-SE and NE-SW.

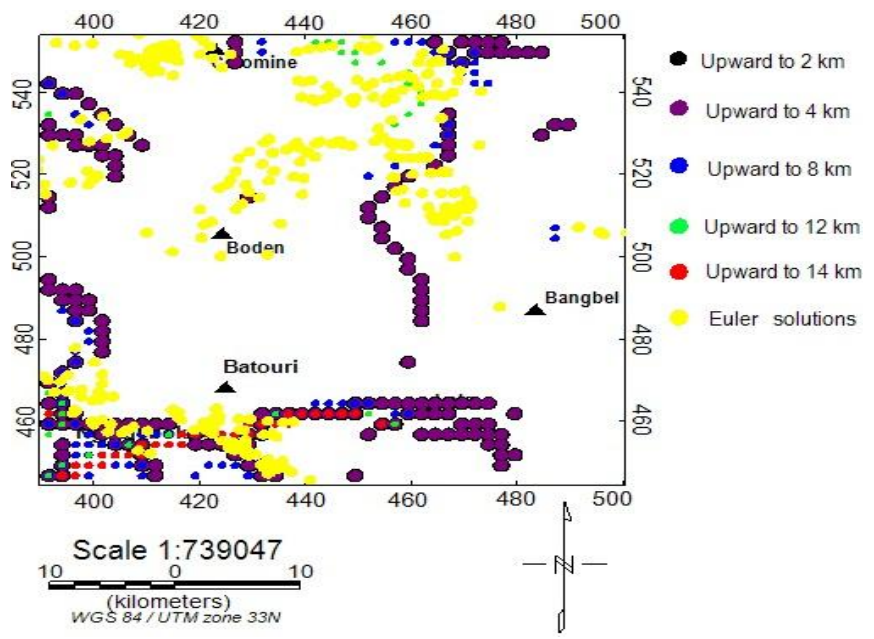

Figure 9: Estimated locations of contacts according to the horizontal gradient coupled with upward continuation and Euler deconvolution method.

\subsection{Lineaments Map of the Studied Area}

The results obtained after applying the treatment process Euler anomalies of the gravity field of the region allow us to identify and confirm the position of delicate geological structures in the crust and identified by the geological studies. Moreover, they allow the knowledge of new lineaments. In (Fig. 9), the main boundary between the high density areas of discontinuity would likely potential sites infiltration dense materials in the costs of the investigation region. Furthermore, to characterize the set of fractures having affected this Pan-African coverage, extended horizontal gradient map up to altitudes ranging from 2, 4, 8 , 12 and $14 \mathrm{~km}$ was performed (Fig. 11).

Table 1 presents the directions of fractures that fit the various lineaments observed on the structural map of the study area (Fig. 11). The main tectonic directions obtained after analysis are: $\mathrm{N} 109^{\circ} \mathrm{E}, \mathrm{N} 133^{\circ} \mathrm{E}$ and $\mathrm{N} 102^{\circ} \mathrm{E}, \mathrm{N} 0{ }^{\circ} \mathrm{E}$. 


\section{International Journal of Science and Research (IJSR) \\ ISSN (Online): 2319-7064 \\ Index Copernicus Value (2013): 6.14 | Impact Factor (2014): 5.611}

With a general trend in the NW-SE and WNW-ESE direction. Thus, the lineaments in the basement associated with positive anomalies in Batouri southern region have been created in the crust during the Pan African orogeny and seem to correspond to subsurface structures produced during the collision tectonics border between Craton and the PanAfrican

chain.

Moreover, these lineaments characteristic of negative anomalies north of Batouri to Colomine and could be associated with the orogenesy of intrusion granitic (granitoids pan-African) in the upper crust in magmatic eruptions observed at the Sanaga Fault. In Figure 12, the distribution of the main directions of lineaments identified in the area was determined using rose diagram.

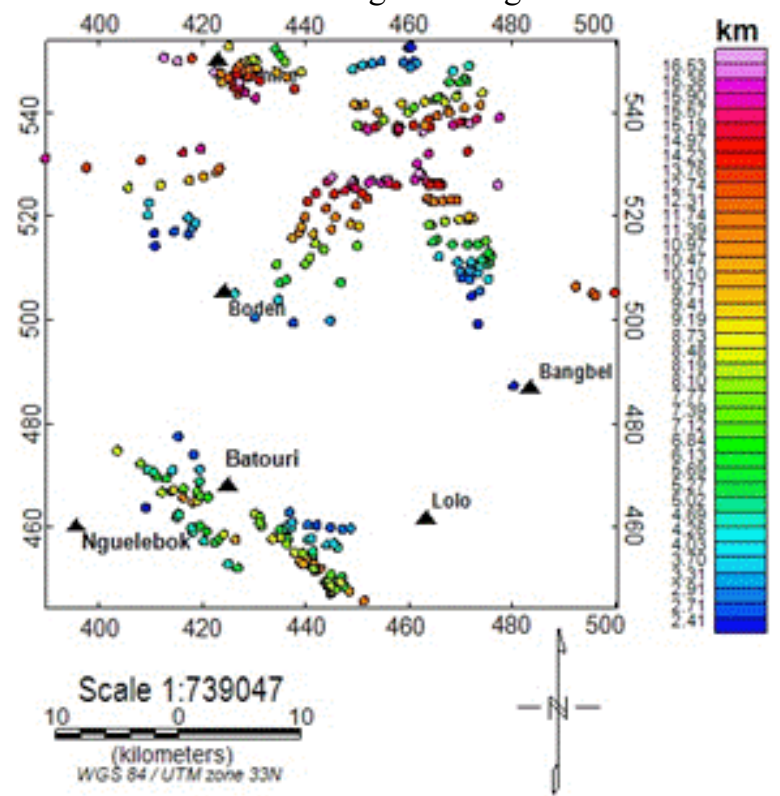

Figure10: The Euler depths of the study area

Table 1: Orientation of different lineament segments

\begin{tabular}{|c|c|c|c|}
\hline$N^{\circ}$ & Oriestation & $N^{6}$ & Orientation \\
\hline 1 & N109: & 10 & $\mathrm{~N} 147^{\circ} \mathrm{E}$ \\
\hline 2 & $\mathrm{~N} 140^{\circ} \mathrm{E}$ & 11 & N137\%E \\
\hline 3 & N98 $E$ & 12 & No'E \\
\hline 4 & N133'E & 13 & No'E \\
\hline 5 & N123:E & 14 & N133E \\
\hline 6 & No $\mathrm{E}$ & 15 & No E \\
\hline 7 & No'E & 16 & $\mathrm{~N} 102^{\circ} \mathrm{E}$ \\
\hline 8 & N60 $60^{\circ}$ & 17 & N51'E \\
\hline 9 & N51 ${ }^{\circ} \mathrm{E}$ & 18 & N136 E \\
\hline
\end{tabular}

\section{Discussion}

This study area has in the past been the subject of many geophysical and geological studies at the regional and local level, the most recent are those of [4-6-24-25]. Among the new results brought by this work is cited:

1) Discontinuities in the crust are essentially confined to the upper part of the crust is up to16 kilometers. They would nevertheless be related to major frontal area of over lapin the area of Cameroon center, south and north of the suite area magmatic lifts in the series of Lom.

2) Gravimetric lineaments up to $4^{\circ} 30^{\prime}$ parallel suggest that the sector has suffered a geological remodeling associated Congo Craton and the Pan-African belt in the areas major setback charge of the area.
3) The basic structures of gravity are determined in accordance with neoprotozoic formations, and are linked to the foliation zone plane and stretching lineation called $\mathrm{S}_{1-2}$ and $\mathrm{L}_{2}$, a pan-African coverage stretching from western Cameroon in Sudan [1-5]. Moreover, the mass heterogeneous network identified in the study area, with a significant trend WNW-ESE to NW-SE is also connected to the CC-CPNE collision.
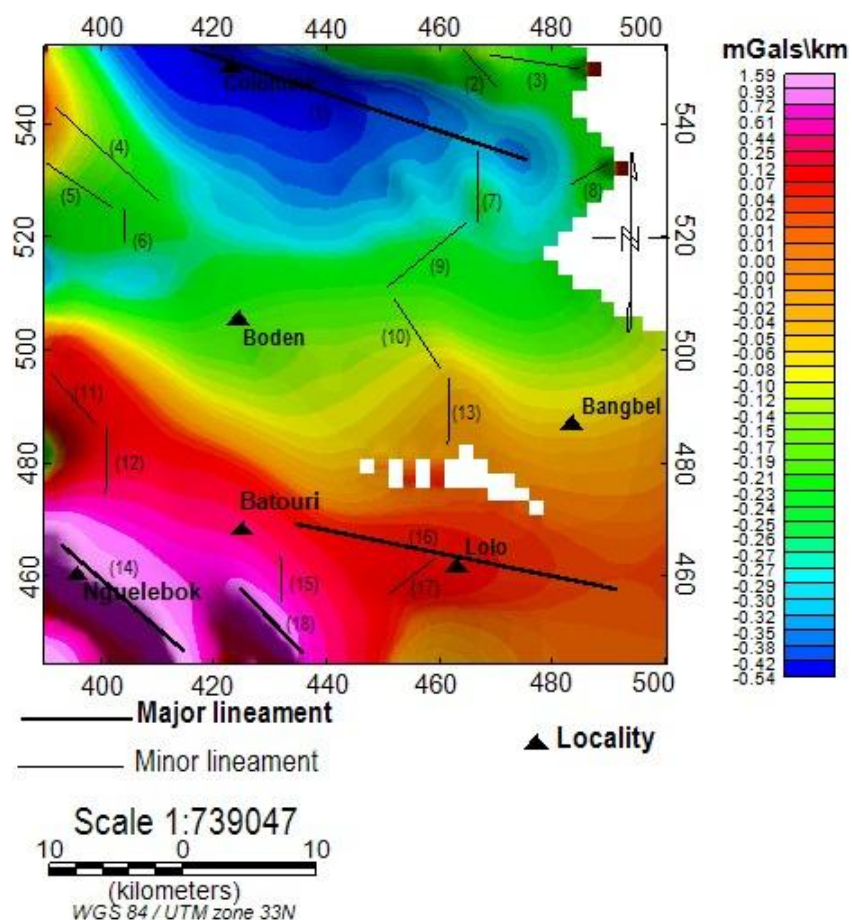

Figure 11: Gravity lineament map obtained for the study area superimposed on the horizontal gradient map.

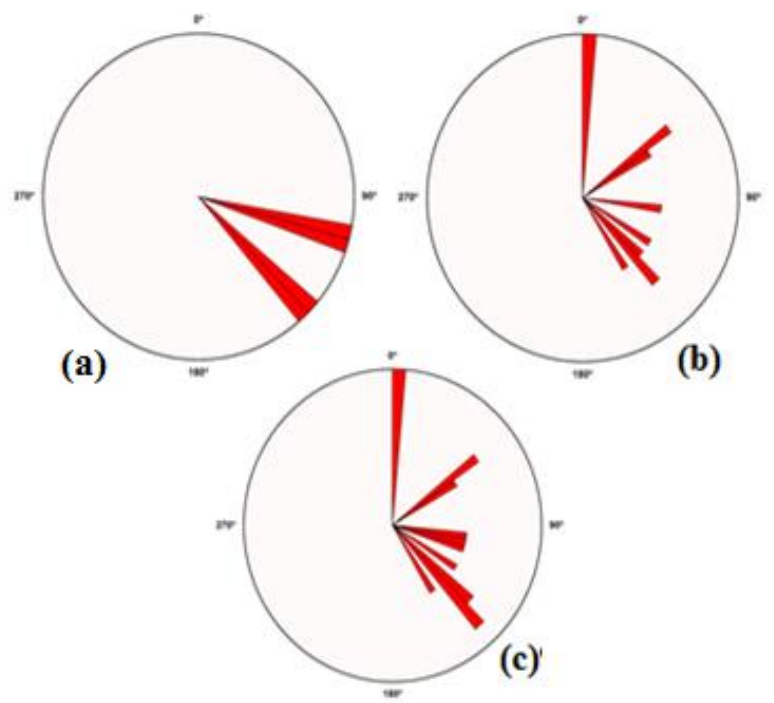

Figure 12: (a) Rose diagram of the major lineament orientations; (b) Rose diagram of the minor lineament orientations; (c) Rose diagram of the general lineament orientations of the study area.

\section{Conclusion}

The Bouguer anomalies map obtained in this study allowed us to locate the geophysical signature comparable to panAfrican structures north (granite) and southern (basic 


\section{International Journal of Science and Research (IJSR) \\ ISSN (Online): 2319-7064}

Index Copernicus Value (2013): 6.14 | Impact Factor (2014): 5.611

Complex) in the study area. The arrangement of these two structures was distinguished from all the anomalies of the gravity field cards shown after Batouri-Lolo and ColomineNguelebok axis. The analysis of the different signatures assigned to each anomaly respectively was determined structural features for high elevations of 2 to $14 \mathrm{~km}$.

From this analytical continuation, it appears that the tectonics of the region is characterized by a set of major lineaments (N109 ${ }^{\circ} \mathrm{E}, \mathrm{N} 133^{\circ} \mathrm{E}$ and $\left.\mathrm{N} 102^{\circ} \mathrm{E} \mathrm{N} 0{ }^{\circ} \mathrm{E}\right)$ and minor. To estimate the depth of the sources of these lineaments in different places, we applied the Euler deconvolution and have retained as depths 2 to $16 \mathrm{~km}$ for detected environments. In addition, the horizontal gradient map, it is observed that these structures identified in the area are sites that may contain exploitable resources for economic purposes.

\section{Acknowledgements}

The authors thanks to the reviewers, for their kind remarks making the manuscript clearer and more pertinent.

\section{References}

[1] T. Ngnotué, J.P. Nzenti, P. Barbey, and F. M. Tchoua, 2000 The Ntui-Betamba high grade gneisses in Cameroon. Journal of African Earth Sciences, Vol. 31, $\mathrm{n}^{\circ} 2$, pp. 369-381.

[2] J.P.Nzenti, 1992. Prograde and retrograde garnet zoning at high pressure and temperature in metapelitic and grenatite rocks from Yaoundé, Journal of African Earth Science., vol. 15, pp. $73-79$

[3] V. Ngako, P. Affaton, J. M. Nnange, T. Njanko, 2003. Pan-African tectonic evolution in central and southern Cameroon: transpression and transtension during sinistral shear movements. Journal of African Earth Sciences 36 207-214.

[4] D. Gouet, T.M. Ndougsa, A. Meying, S.P. Assembe, and A.D. Man-Mvele-Pepogo, 2013. Gold mineralization channels identification in the Tinkala-Boutou area (Eastern-Cameroon) using geoelectrical (DC et IP) methods. International Journal of Geosciences, vol. 4, p.643-655.

[5] S.F. Toteu, W.R. Van schmus, J. Penaye, A. Michard, 2001. New U-Pb and Sm-nd data from north-central Cameroon and its bearing on the pre-Pan African history of central Africa. Precambrian Research 108: 45-73.

[6] C.E. Suh, B. Lehman, and G.T. Mafany, 2006. Geology and geochemical aspects of lode gold mineralization at Dimako-Mboscorro, SE Cameroon. Geochemistry:Exploration, Environment, Analysis, vol. 6(4), p. 295-309.

[7] J. Gazel, et G. Gerard, 1954. Carte géologique de reconnaissance du Cameroun au 1/500 000coupure Batouri-Est avec une notice explicative de 50p. Arch De la Direction des Mines et de la Géol. Du Cameroun. Yaoundé.

[8] J.P. Nzenti, P. Barbey, P. Jegouzo and C.Moreau, 1984. Un nouvel exemple de ceinture granulitique dans une chaîne protérozoïque de collision : les migmatites de Yaoundé au Cameroun. Comptes Rendu de l'Académie des Sciences de Paris, 299: 1197-1199.
[9] Y.H. Poudjom-Djomani, A. Legeley-Padovani, D.B. Boukeke, J.M. Nnange, Y.Ateba-Bekoa, Y. Albouy, and J.D. Fairhead, 1996. Levés gravimétriques de reconnaissance du Cameroun. Mémoire ORSTOM, France, $38 \mathrm{p}$.

[10] S. Mbom-Abane, 1997. Investigations géophysiques en bordure du Craton du Congo (région AbongMbang/Akonolinga - Cameroun) et implications structurales. Thèse de Doctorat d'État, Université de Yaoundé I, $180 \mathrm{p}$.

[11]T. Ndougsa-Mbarga, E. Manguelle-Dicoum, S. MbomAbane, \&C.T. Tabod, 2002.Deep crustal structures along the north eastern margin of the Congo Craton in the Abong-Mbang/Bertoua region (Cameroon) based on gravity data. In: Electronics Memories of the $2^{\text {nd }}$ Cuban Geophysical Congress and the IV Latin American Geophysical Conference, 2002, Cuba, CD Rom pp. 15.

[12] R.J. Blakely and R.W. Simpson, 1986. Approximating edges of source bodies from magnetic or gravity anomalies Geophysics, 51, 1494-1498.

[13] J. D. Phillips, 2000.Locating magnetic contacts: a comparison of the horizontal gradient, analytic signal, and local wavenumber methods. In: SEG 70th Annual International Meeting, Expanded Abstract.

[14]J.D. Phillips, 1998.Processing and Interpretation of Aeromagnetic Data for the Santa Cruz Basin Patahonia Mountains Area, South-Central Arizona.U.S. Geological Survey Open-File Report, Arizona, 02-98.

[15] M.L.C.OwonaAngue, T.C.Tabod, N. Séverin, K.J. Victor, and T.A.P. Kamga, 2013.Delineation of Lineaments in South Cameroon (Central Africa) Using Gravity Data.Journal of Geology, vol. 3, p.331-339.

[16] K.W. Biyiha,M.T. Ndougsa, Y.J.Q. Atangana, P.C. Ngoumou, and T.C.Tabod, 2013.2.5D Models Derived from the Magnetic Anomalies Obtained by Upward Continuation in the Minbi Area Southern Cameroon. Journal of earth sciences and Geotechnical Engineering 4(3), p.175-199.

[17] A.B. Reid, J.M.Allsop, H. Granser, A.J. Millet, and I.W. Somerton, 1990. Magnetic interpretation in three dimensions using Euler deconvolution. Geophysics 55, 180-191.

[18]D.T.Thomson, 1982.Euldph: A new technique for making computer-assisted depth estimates from magnetic data. Geophysics 47, 31-37.

[19]L. Cordell, 1979. Gravimetric expression of graben faulting in Santa Fe country and the espanola basin, New Mexico. In: Ingersoll, R. V., (Ed.), Guidebook to Santa Fe country: New Mexico Geol. Soc. Guidebook. 30th Field Conference, 59-64

[20] L.Cordell, and V. J. S. Grauch, 1985.Mapping basement magnetization zones from aeromagnetic data in the San Juan basin, New Mexico. In. Hinze, W. J., (Ed.), The utility of regional gravity and magnetic anomaly Maps: Society of Exploration Geophysicists, 181-197.

[21] V. J. S. Grauch, M. R. Hudson and S. A.Minor, 2001. Aeromagnetic expression of faults that offset basing fill, Albuquerque basin, New Mexico. Geophysics 66, $707-$ 720.

[22] T.C.Noutchogwe, C.T. Tabod, andE.ManguelleDicoum, 2006. A gravity study of the crust beneath the Adamawa fault zone, West Central Africa. J. Geophys. Eng., 3, 82689. 


\section{International Journal of Science and Research (IJSR) \\ ISSN (Online): 2319-7064}

Index Copernicus Value (2013): 6.14 | Impact Factor (2014): 5.611

[23] Marson, E.E. Klingele, 1993. Advantages of using the vertical gradient of gravity for 3-D interpretation, Geophysics, 58, 1588-1595.

[24] J.M.Tadjou, E.Manguelle-Dicoum, C.T.Tabod, R. Nouayou, J. Kamguia, N. P.Njandjock and M. T. Ndougsa, (2004): Gravity modelling along the northern margin of the Congo craton, South-Cameroon, J. Cameroon Acad. Sci., 4, 51-60.

[25] A.Z. Amougou, T.N.Mbarga, A.Meying, D.Y. Layu, M. Bikoro, and E.M.Dicoum, 2014. 2.5D Modelling of Crustal Structures along the Eastern Cameroon and Western Central African Republic Derived from Finite Element and Spectral Analysis Methods. Geophysica. Rev. Lett, vol. 49 (1-2), p.75-79.

\section{Author Profile}

Ngoumou Paul Claude received the PhD Degree in Geophysics and Geoexploration from the University of Yaoundé I in 2015. He is presently Assistant Lecturer in the Department of Physics Advanced Teachers' Training College, University of Yaoundé I. He also acting as Part time Senior Lecturer in the Preparative course for many Higher Colleges of Engineering (PrepaVogt),of France. His current research interest includes: filtering potential field data and their 2.5D or 3D modeling for onshore sedimentary basins \&Cratonic areas. He also specialize in the collecting and interpretation of geoelectrical data.

Owona Angue M.L.C. received the PhD Degree in Geophysics in 2011 from the University of Yaoundé I in 2011. He is presently Senior Lecturer in the Department of Physics Advanced Teachers' Training College, University of Yaoundé I. He has more than 25 years experience in teaching physics, geophysics and mining exploration courses.

Bikoro Bi Alou Marcelin completed his M.Sc. in Geophysics at the Faculty of Science in the University of Yaounde I, and he is presently on the way to defend his $\mathrm{PhD}$ in the same University. He is presently Assistant Lecturer in the Department of Earth Sciences, University of Maroua.

Wandji Kamwa Joseph Antoine completed his M.Sc. in Geophysics and Geoexploration at Postgraduate School of Science, Technology And Geosciences University of Yaoundé I. He is presently working on his $\mathrm{PhD}$ focused on the filtering, analysis and interpretation of magnetic data.

Owono Amougou O.U.I completed his M.Sc. in Geophysics and Geoexploration at Postgraduate School of Science, Technology And Geosciences University of Yaoundé I. He is presently working on his $\mathrm{PhD}$ focused on the filtering, analysis and interpretation of magnetic data and their $2.5 \mathrm{D}$ or $3 \mathrm{D}$ modelling. He has submitted some papers in international journals.

Prof. Ndougsa-Mbarga Théophile completed his B. Sc., PGDE in Physics \& the M.Sc. and PhD in Geophysics, respectively at the Advanced Teacher's Training College (ATTC) and the Faculty of Science in the University of Yaoundé I. He obtained Diplomas in Mining Exploration-Exploitation and Petroleum Management respectively in Witwatersrand and Pretoria Universities (South Africa Republic) and in PETRAD Programme (NPD, Norway). He is presently Senior Lecturer in the Department of Physics, ATTC (ENS), and Director of Geology in the Ministry of Industry, Mines and Technological Development of Republic of Cameroon. 